of the kind of organism, $b$ is the scaling exponent

West et al. proposed a theoretical model on the scaling law[1]. This model suggests the relation on the scaling exponent as $b=D /(D+1)$, where $D$ is a geometrical dimension. The relation induces $b=3 / 4$ in the three dimensional organisms such as mammals, birds, and etc. This well agrees with the previous experimental observations.

This study investigates how the geometrical dimension effects on the scaling exponent with the use of Physarum plasmodium. The plasmodium is an amoeboid unicellular organism that has vascular network and spread on two-dimensional plane under intact condition. Gomi and Takamatsu reported the scaling exponent $b$ for the two-dimensional plasmodium approximates $2 / 3$ rather than $3 / 4[2]$. To verify whether the relation $b=D /(D+1)$ also holds on one-dimensional organisms, we investigated the relation between organism's body mass and oxygen consumption in Physarum plasmodium controlled into one dimensional shape.

[1] Geoffrey B. West, A General Model for the Origin of Allometric Scaling Laws in Biology, SCIENCE VOL. 276(1997)

[2] Takuma Gomi, Atsuko Takamatsu, Allometric scaling law in two dimensional organism, Physarum plasmodium, The 45th Annual meeting of the Biophysical Society of Japan in Pacifico Yokohama, 1P283(2007)

\section{P-302 真正粘菌変形体における環境依存の輸送管ネットワーク解析}

Analysis on environment dependent transportation network structure in plasmodium of true slime mold

Masateru Ito, Atsuko Takamatsu, Riki Okamoto. (Electrical Engineering and Bioscience, Graduate School of Advanced Science and Engineering, Waseda Univ)

Plasmodium of true slime mold, Physarum polycephalum, is a giant multinucleaed unicellular organism, in which the single cell size rages from about $10 \mu \mathrm{m}$ to $100 \mathrm{~cm}$. In the growth process, tubular network structures are formed and in each tube shuttle stream carries protoplasm including nutrients. Interestingly, the configuration of the tubular network and the tube diameter change dramatically depending on environments, while the flow rate of protoplasm depends on the tube diameter. Thus, transportation capacity of protoplasm would relate to both the network topology and the distribution of tube diameter. Therefore, the tubular network structures would play important roles in adaptation to environments.

We analyzed the environment dependent topology of transportation networks as complex networks [1]. We found the network formation tends to be plane lattice in the pleasant environment for the plasmodium, on the other hand, to be tree-graph in the unpleasant one.

We continue to analyze the tubular network structure as complex networks by obtaining information on the distribution of tube diameter in addition to the information on network topology. We found the tubular networks consist of a lot of thin tubes in the pleasant environment. By contrast, thick tubes grow outstandingly in the unpleasant one. We discuss characteristics of the networks in the two environments and an adaptation mechanism by environment dependent network morphology.

[1] M.Ito and A.Takamatsu, Proceedings of 20th Symposium on Autonomous Distribution (2008), pp.337-342

\section{P-303 生化学データに基づくシステムシミュレータの開発:大腸菌二段 増殖のシミュレーション}

Development of a cellular simulator based on biochemical data: Ssimulation of E.coli diauxie

Kaneko Haruki, Kato Yuka, Itoh Seigo, Ando Tadashi, Yamato Ichiro.Faculty of Industrial Sscience and Technology, Tokyo University of Science.

Various "-Omics" researches have progressed dramatically, which have produced extensive data of biological systems. Under this circumstance, simulating a whole cell for understanding a biological system at system-level has become practical. In this study, we developed a cellular simulator to simulate behaviors of a whole bacterial cell system. This software has three distinctions as followings: 1) It displays a biological network graphically to facilitate understanding these systems. 2) It uses biochemical data as much as possible to reflect biochemical mechanisms. 3) To predict behavior of a whole cell, various reaction processes in a cell in addition to metabolic processes are included. We collected parameters required for simulation, such as $\mathrm{Km}$, kcat and $\mathrm{Keq}$, from literatures, and simulated lac gene expression networks and lactose metabolic pathways with glucose phosphotransferase system of E.coli growing in the presence of lactose and glucose A two-phase production of ATP like that of "diauxie" growth was observed. It has been believed that inducer exclusion and catabolite repression are both important for diauxie. However, recently, it was reported that there is no difference of cAMP concentration between at the phases of glucose and lactose growth. When we simulated with constant cAMP concentration, diauxie was observed similarly. This result supports the experimental result that diauxie was mainly controlled by the activation of lactose repressor due to inducer exclusion.

\section{P-304 ショウジョウバエ翅形成において細胞・組織に働くカ学過程の解} 析

Analyzing mechanical processes in the growth of Drosophila wing

Shuji Ishihara (1) and Kaoru Sugimura (2). (1. Dept Basic Science, Graduate School of Arts and Sciences., Univ of Tokyo; 2. RIKEN)

Mechanical properties of the growing tissue recently attract much attention in developmental biology, because they are indispensable to understand physical processes responsible for determining the final size, shape and proportion of an organ. However, it is yet unclear how volume- and shear- elasticity of a tissue are derived from the nature of the constituent cells. Also, there has been no quantitative measurement to evaluate physiological parameters associated with the mechanical properties. To elucidate the roles of mechanics in development, we have studied growth of Drosophila wing by integrating experimental and theoretical approaches. In the presentation, we will mainly show theoretical part of our studies.

1. Based on theoretical models (GGH or Vertex Cell models) that consider cell elasticity and adhesion, we derived elastic coefficients of a tissue. Moreover, we found instability of cell size distribution arises (i.e. phase transition). We compared the theoretical prediction with the morphological defects in Drosophila wing that were caused by changing the expression of the regulators of cell adhesion and/or acto-myosin network.

2. We are developing a method to estimate the intercellular surface tensions and volume-elasticities of cells. Mathematical framework of the method involves the derivation of balance equations from the observed data set, and solving the inverse problem under appropriate assumptions. The method is applied for the Drosophila wing growth.

\section{P-305アゾポリマの光誘起変形機能を用いた細胞骨格フィラメントの運 動制御}

Controlled movement of cytoskeletal filaments by the photoinduced relief structure on azopolymer.

Taiji Ikawa (1), Masahito Shiozawa (1), Mamiko Narita (1), Makoto Mouri (1), Fumihiko Hoshino (1), Osamu Watanabe (1). Masaki Edamatsu (2) and Yoko Yano Toyoshima (2) (1:Toyota Central R\&D Labs., Inc.; 2: Dept Life Sci, Graduate School of Arts \& Sciences, The Univ of Tokyo)

We demonstrate a simple technique for the directional control of the sliding movement of cytoskeletal filament using a photoresponsive polymer containing azobenzene. The polymer has two specific roles in this technique. One is an intended template for guiding the cytoskeletal filament movement based on a photo-deformation process of the polymer; formation of surface relief gratings by an interference pattern of light. Another is a photo-immobilization of motor proteins on the polymer surface because of the molecular imprinting process; the polymer surface deforms along with shapes of adsorbed macromolecules. In the experiment, firstly, the relief gratings ranging from $500 \mathrm{~nm}$ to $2000 \mathrm{~nm}$ pitch were formed on the films of the polymer by exposure to interference patterns of $488 \mathrm{~nm}$ wavelength light. Next, heavymeromyosin from rabbit skeletal muscle was adsorbed on the polymer and then immobilized by exposure to light from blue-LEDs. Finally, fluorescent actin filaments and $1 \mathrm{mM}$ ATP solutions were sequentially introduced. The movement of actin filaments was observed to be influenced by the shape of the relief structure. The structure with smaller pitch led the uniaxial-like movement of the filaments along the groove of the polymer surface.

\section{P-306 DNA メモリ技術を用いた金基板上での DNA 空間分布の記録法の開 発}

Development of recording method for DNA spatial distribution patterns on a gold surface

GunWoo Kim (1), Kohichiroh Shohda (1), Kenzo Fujimoto (2) and Akira Suyama (1). (1 Department of Life Sciences, Graduate School of Arts and Sciences, The University of Tokyo, 2: School of Materials Science, JAIST)

In situ hybridization technique that can detect spatial distributions of mRNA in a tissue sample has a demerit which can detect limited kinds of mRNA because of wavelength overlapping of dyes in probes. To detect many kinds of mRNA distributions, we try to fix spatial distributions information of mRNA on the gold surface using DNA-ROM technique, which we have already developed[1].

In this study, we have researched that spatial distribution information of DNA on a gold surface could be transferred to another gold surface. We prepared two DNA memories. One is a sample-DNA memory, which consists of a memory-DNA and a data-DNA complementary with the memory-DNA. The other is a device-DNA memory on which the memory-DNA strands are fixed. And we used electrophoresis to transfer the data-DNA from the sample-DNA memory to the device-DNA memory. Temperature, salt concentration, DNA sequence, gel concentration, etc were examined to obtain high resolution DNA pattern.

We made a circle pattern $2 \mathrm{~mm}$ in diameter with the data-DNA in the sample-DNA memory. And we confirmed an obscure circle pattern about $2 \mathrm{~mm}$ in diameter on the device-DNA memory. We aim to $500 \mu \mathrm{m}$ spatial resolution which is the size of some cells.

[1] DNA-ROM based on photoligation and DNA molecular addressing on a gold surface, GunWoo Kim. et al, 44th Annual Meeting of the Biophysical Society of Japan, December 21-23, 2007, Yokohama.

\section{$1 \mathrm{P}-307$ 球殻上タンパク質アポフェリチンを用いた化合物半導体 ZnS ナ ノ粒子の作製}

Synthesis of ZnS compound semiconductor nano-particle in an apoferritin cavity Kenji Iwahori (1), Hirotoshi Furusho (2), Ichiro Yamashita (1,3) (1: Dept. Materials Science Graduate School of Nara Institute Science and Technology; 2; Research Center for Ultra-High Voltage Electron Microscopy, Osaka University; 3: Advanced Technology Research Laboratories, Matsushita Electric Industrial Co., Ltd.) 